\title{
Quantification of muscle recovery methods by near-infrared spectroscopy after heavy exercise in the heat
}

\author{
Sirkka Rissanen*, Satu Mänttäri, Juha Oksa \\ From 15th International Conference on Environmental Ergonomics (ICEE XV) \\ Portsmouth, UK. 28 June - 3 July 2015
}

\begin{abstract}
Introduction
Recovery of muscle function after heavy physical work may last for several hours [1]. This study compared four different recovery modalities to passive recovery during $4 \mathrm{hrs}$ follow-up after heavy exercise period while wearing firefighting protective equipment in a hot environment.
\end{abstract}

\section{Methods}

Thirteen male firefighters volunteered in the study. They performed an exercise track which contained sledge hammering, going under and over an obstacle, stair walking, hose rolling and walking with and without loads. The exercise lasted for $20 \mathrm{~min}$ and the volunteers were asked to perform the exercise as hard as possible but keeping in mind to be able to complete the whole test. They wore firefighting smoke diving protective clothing (ca. 2 clo), helmet, gloves and boots and carried an Air-Pak cylinder in a backpack. Regulator and facemask were not used. Ambient temperature was $35{ }^{\circ} \mathrm{C}$ and $\mathrm{rh} 30 \%$. Heart rate and rectal temperature were measured during the exercise. Following the exercise, volunteers took off the protective equipment. Recovery process was followed at room temperature for 4 hours. The five recovery modalities were: 1 ) caffeine ingesting (CI, 6 mg.kg- ${ }^{1}$ ), 2) forearm stretching (S), 3) forearm cold water $\left(15^{\circ} \mathrm{C}\right)$ immersion $\left.(\mathrm{C}), 4\right)$ forearm cold $\left(15^{\circ} \mathrm{C}\right)$ and warm $\left(37^{\circ} \mathrm{C}\right)$ water immersion $(\mathrm{CW})$ and 5$)$ reference (REF) without any intervention. CI, S, C and CW were applied at 20, 40 and $80 \mathrm{~min}$ after the exercise. Recovery follow-up was focused on the right forearm (wrist flexor) and were performed at $0,30,60,120$ and $240 \mathrm{~min}$ after the exercise and was performed at sitting position.

\footnotetext{
* Correspondence: sirkka.rissanen@ttl.fi

Physical Work Capacity, Finnish Institute of Occupational Health, Oulu,
} Finland creativecommons.org/licenses/by/4.0), which permits unrestricted use, distribution, and reproduction in any medium, provided the original work is properly cited. The Creative Commons Public Domain Dedication waiver (http://creativecommons.org/publicdomain/ zero/1.0/) applies to the data made available in this article, unless otherwise stated.

\section{Conclusion}

All four active recovery modalities increased muscle $\mathrm{VO}_{2}$ and all except $\mathrm{CI}$ increased $\mathrm{ReO}_{2}$ rate after heavy exercise in the heat in comparison to reference. The most pronounced effect was observed in $\mathrm{ReO}_{2}$ rate at 60 and $120 \mathrm{~min}$. The greater increase in $\mathrm{mVO}_{2}$ and $\mathrm{ReO}_{2}$ rate after these recovery interventions are indicative of increased metabolic rate and probably faster recovery process in the muscle.

\section{Acknowledgements}

This study was supported by The Finnish Work Environment Fund.

Published: 14 September 2015 


\section{Reference}

1. Oksa J, Rintamäki H, Takatalo K, Mäkinen T, Lusa S, Lindholm H, Rissanen S:

Firefighters muscular recovery after a heavy work bout in the heat. Appl Physiol Nutr Metab 2013, 38(3):292-9.

doi:10.1186/2046-7648-4-S1-A8

Cite this article as: Rissanen et al:: Quantification of muscle recovery

methods by near-infrared spectroscopy after heavy exercise in the heat.

Extreme Physiology \& Medicine 2015 4(Suppl 1):A8.

Submit your next manuscript to BioMed Central and take full advantage of:

- Convenient online submission

- Thorough peer review

- No space constraints or color figure charges

- Immediate publication on acceptance

- Inclusion in PubMed, CAS, Scopus and Google Scholar

- Research which is freely available for redistribution

Submit your manuscript at www.biomedcentral.com/submit
Ciomed Central 